\title{
Panhypopituitarism due to Wegener's granulomatosis
}

\author{
Pan-hipopituitarismo causado pela granulomatose de Wegener
}

Silvina G. Santoro', Alberto H. Guida², Alejandra E. Furioso', Patricia Glikman', Amelia S. Rogozinski'

1 Department of Endocrinology, Hospital General de Agudos Dr. Profesor J. M. Ramos Mejía. CABA, Argentina 2 Department of Internal Medicine, Hospital General de Agudos Dr. Profesor J. M. Ramos Mejía. CABA, Argentina

Correspondence to: Silvina G. Santoro Calle 149, número 1435 Berazategui

CP 1884 - Buenos Aires, Argentina silvinasantoro@yahoo.com.ar

Received on July/20/2011 Accepted on Sept/22/2011

\section{SUMMARY}

Wegener's granulomatosis (WG) is a multi-system necrotizing granulomatous vasculitis which classically affects the upper respiratory tract, lungs and kidneys. Pituitary participation has been described in 24 patients in the literature to date. The aim of this article is to report a case of pituitary involvement in WG, and to present a literature review on this association. We present a female patient with WG who evolved with central diabetes insipidus (CDI), panhypopituitarism, and mild hyperprolactinemia. MRI showed an infiltrative pattern. Pituitary involvement has been reported in around $1 \%$ of patients with WG, mostly in women. It is represented by CDI and hypopituitarism. MRI generally shows pituitary enlargement, stalk thickening and loss of hyperintensity of the neurohypophysis. Permanent endocrine therapy is generally needed. WG should be considered in cases of CDI and hypopituitarism, essentially if a vasculitis is suspected and more common sellar disorders have been ruled out. Arq Bras Endocrinol Metab. 2011;55(7):481-5

\section{SUMÁRIO}

A granulomatose de Wegener (GW) é uma vasculite necrotizante multissistêmica que afeta classicamente o trato respiratório superior, pulmões e rins. 0 envolvimento da hipófise foi descrita em 24 pacientes na literatura, até hoje. 0 objetivo deste artigo é relatar um caso de GW com envolvimento pituitário, e apresentar uma revisão da literatura sobre esta associação. Apresentamos uma paciente com GW que evoluiu para diabetes insipidus central (DIC), panhipopituitarismo e leve hiperprolactinemia. A RM mostrou um padrão infiltrativo. 0 envolvimento da hipófise foi relatado em cerca de $1 \%$ dos pacientes $\mathrm{cm} \mathrm{GW}$, na sua maioria mulheres. A desordem é representada por DIC e hipopituitarismo. A RM geralmente mostra o aumento da hipófise, aumento da espessura da haste, e perda da hiperintensidade da neurohipofise. Normalmente, é necessária terapia endócrina permanente. A GW é geralmente considerada nos casos de DIC e hipopituitarismo, essencialmente se há suspeita de vasculite e quando desordens selares mais comuns foram descartadas. Arq Bras Endocrinol Metab. 2011;55(7):481-5

\section{INTRODUCTION}

Cystemic inflammatory and granulomatous diseases $\checkmark$ are rare causes of pituitary disorders. Numerous diseases have been described to potentially compromise sellar function and morphology, such as fungal infections, sarcoidosis, Langerhans' cells histiocytosis, idiopathic giant cell granulomatous hypophysitis, Takayasu's disease, Cogan's syndrome, and Crohn's disease. Among them, WG is described as an unusual cause of partial or global pituitary dysfunction, either at onset or in the course of the disease (1).
Wegener's granulomatosis (WG) is a multi-system necrotizing granulomatous small-vessel vasculitis. Although its etiology is not fully understood yet, it has been largely associated to anti-neutrophil cytoplasmic antibodies (ANCA), especially to proteinase 3 ANCA (2).

WG is classically defined by involvement of the triad of upper respiratory tract, lungs and kidneys. However, because of its multi-system nature, it may also affect any other tissue or organ. Thus, participation of mucous-cutaneous areas, joints or eyes has been frequently reported (3). 
As for pituitary involvement in WG, it has been typically referred as CDI, which was first reported by Ahlström and cols., in 1953 (4). Nevertheless, although it is less frequent, WG may additionally lead to anterior pituitary involvement (5).

Approximately 24 cases of pituitary involvement in WG have been reported in the literature so far $(6,7)$. The aim of this article is to describe a case of pituitary involvement in a patient with previous diagnose of WG, and to make a brief discussion of pituitary involvement in WG.

\section{CASE REPORT}

A 53 year-old woman was referred for endocrine evaluation due to clinical suspicion of CDI, in the context of admission to the Internal Medicine Unit for anasarca related to her previous diagnosis of WG.

She had been formerly admitted to the Dermatology Unit of our institution three months before, because of a pretibial ulcer on her left leg associated to generalized symmetrical arthritis of small joints and papular lesions in both legs.

At anamnesis, the patient referred to diagnosis of hypertension of five years of evolution, Raynaud syndrome, and four spontaneous abortions. However, she also referred to normal cycles since menarche at 12 years old until menopause at 48 years old, without climacteric syndrome.

She evolved with fever associated with productive cough, hypotension and deterioration of clinical status. A computed tomography revealed a caveated lesion in the lower left pulmonary lobe, and an additional X-ray showed sinusitis, requiring 21 days of treatment with amoxillin clavulanate in the clinical context of sepsis. Blood count $(\mathrm{CBC})$ at that moment showed normochromic normocytic anemia, interpreted as related to a chronic disease, associated with discrete eosinophilia. Both $\mathrm{C}$ reactive protein (CRP) and erythrosedimentation rate were elevated.

With clinical suspicion of WG, many complementary tests were performed. First, serum cytoplasmic ANCA (ANCAc) was positive, with the rest of the cholagenogram and proteinogram within the normal range. Histological analysis of both the ulcer on the left leg and the most important papular lesion located in the right upper thigh showed "vasculitis of the small vessels with neutrophilic infiltrate, associated to granulomatous lesions of the hypodermis secondary to vascular sclerosis".
With the histological confirmation of WG, therapy with prednisolone and ciclophosphamide was started. After 29 days, the patient was discharged with this treatment associated with enalapril, folic acid, ferrous sulfate and trimethoprim sulfamethoxazole.

Two months later, she was re-admitted to the Internal Medicine Unit with a diagnosis of anasarca due to confirmed nephrotic syndrome linkable to WG, complicated by spontaneous bacterial peritonitis. Therefore, therapy with ceftriaxone was instituted.

At this admission, the patient evolved to polyuria, low urinary density, and hypernatremia, which led to endocrine evaluation in order to confirm suspicion of CDI. Renal failure and osmotic diuresis were ruled out.

It ought to be noted that hypernatremia could be explained by the fact that, during the days previous to admission and on the first days of hospitalization, the patient had a reduced consciousness that prevented her from having adequate hydration, aggravated by her spontaneous bacterial peritonitis.

Table 1 shows restriction test that confirmed CDI diagnosis. In addition, the patient responded with normalization of diuretic rhythm and ionogram after the instauration of desmopressin therapy $(0.2$ mg, orally TID).

Table 1. Restriction test data. Parameters after instauration of desmopressin therapy are also mentioned

\begin{tabular}{lccc}
\hline & Ionogram & $\begin{array}{c}\text { Urinary density/ } \\
\text { osmolarity }\end{array}$ & $\begin{array}{c}\text { Diuresis } \\
\text { (mL/hour) }\end{array}$ \\
\hline Basal & $153 / 3.8$ & $1007 /<150$ & - \\
\hline 30 minutes after initiation & $156 / 3.6$ & $1005 /<150$ & 300 \\
$\begin{array}{l}\text { Post desmopressin } \\
\text { (1 mg SC) }\end{array}$ & $147 / 4.5$ & $1010 / 326$ & $<150$ \\
$\begin{array}{l}\text { After instauration of } \\
\text { desmopressin therapy } \\
(0.1 \text { mg TID IN) }\end{array}$ & $135 / 4.4$ & $1020 / 349$ & $<150$ \\
\hline
\end{tabular}

SC: subcutaneous; TID: twice daily; IN: intranasal.

With diagnosis of CDI related to WG, an MRI of the sellar area was carried out, which revealed hypointensity of the adenohypophysis in $\mathrm{Tl}$, with hyperintense sectors on its right side in T2, and loss of hyperintense signal of the posterior pituitary. After gadolinium administration, peripheral enhancement 
of the adenohypophysis was described. Discrete thickening of the pituitary stalk was observed as well. Altogether, these findings suggested ischemia of the adenohypophysis and posterior pituitary involvement (Figure 1).

Endocrine laboratory evaluation (chemiluminescence IMMULITE) of the anterior pituitary revealed $\mathrm{LH}=4.4 \mathrm{mUI} / \mathrm{mL}$ (post-menopausal mean 24), $\mathrm{FSH}=8.6 \mathrm{mUI} / \mathrm{mL}$ (post-menopausal mean 41-124), $\mathrm{E} 2=37.2 \mathrm{pg} / \mathrm{mL}$ (post-menopausal 0-30), $\mathrm{TSH}=4.2$ $\mu \mathrm{UI} / \mathrm{mL}(0.6-4.0), \mathrm{T} 4=5.4 \mu \mathrm{g} / \mathrm{dL}(5.0-11.5)$, IGF $\mathrm{l}$ $=45,5 \mathrm{ng} / \mathrm{mL}$ (median 145) GH $0.05 \mathrm{ng} / \mathrm{mL}(0-10)$, $\mathrm{PRL}=18 \mathrm{ng} / \mathrm{mL}(3.0-20.0), \mathrm{FT} 4=0.8 \mathrm{ng} / \mathrm{dL}(0.9-$ $2.0)$ and ATPO $=33 \mathrm{UI} / \mathrm{mL}(<35)$. Note that the level of gonadotropins was not according to age and state of menopause of the patient, and that the level of TSH was not adequate to low free T4, suggesting deficiency in both axes. Therefore, therapy with $50 \mathrm{mcg}$ of levothyroxine was started. Cortisol level was not measured, since the patient was already on steroid therapy due to her WG. The patient evolved satisfactorily, and was discharged with her previous therapy, in addition to intranasal desmopressin $0.1 \mathrm{mg}$ TID, and $50 \mathrm{mcg}$ of levothyroxine daily. With diagnosis of CDI and panhypopituitarism, mainly represented by secondary hypothyroidism and deficit of the gonadal axis, the patient continued her outpatient follow-up in our Department.
It ought to be noted that the dose of levothyroxine was gradually increased to $100 \mathrm{mcg}$ daily, according to laboratories tests. A thyroid ultrasound revealed a normal gland, and determination thyroperoxidase antibodies was repeated, with negative results in two other opportunities.

Cortisol serum levels could only be determined once, since the patient was on steroid therapy for the rest of the time. After one year of steroid treatment discontinuation due to improvement in her disease, basal cortisol was $15.5 \mu \mathrm{cg} / \mathrm{dL}$ (5-25).

Gonadal function remained stable, except from a mild and asymptomatic increment in PRL levels, interpreted as secondary to pituitary stalk thickening. In addition, annual bone densitometries revealed stable mild osteopenia according to age, which satisfactorily responded to therapy with calcium carbonate and cholecalciferol.

Finally, therapy with desmopressin was gradually discontinued, with both a mild increment in thirst and daily diuresis. Neither the patient's quality of life, nor ionogram or other laboratory parameters were significantly altered. Two additional MRIs were performed, after one and three years of diagnosis, without any significant change from basal results. The patient currently remains under cyclophosphamide and enalapril therapy and follow-up is done at the Rheumatology and Internal Medicine Departments.
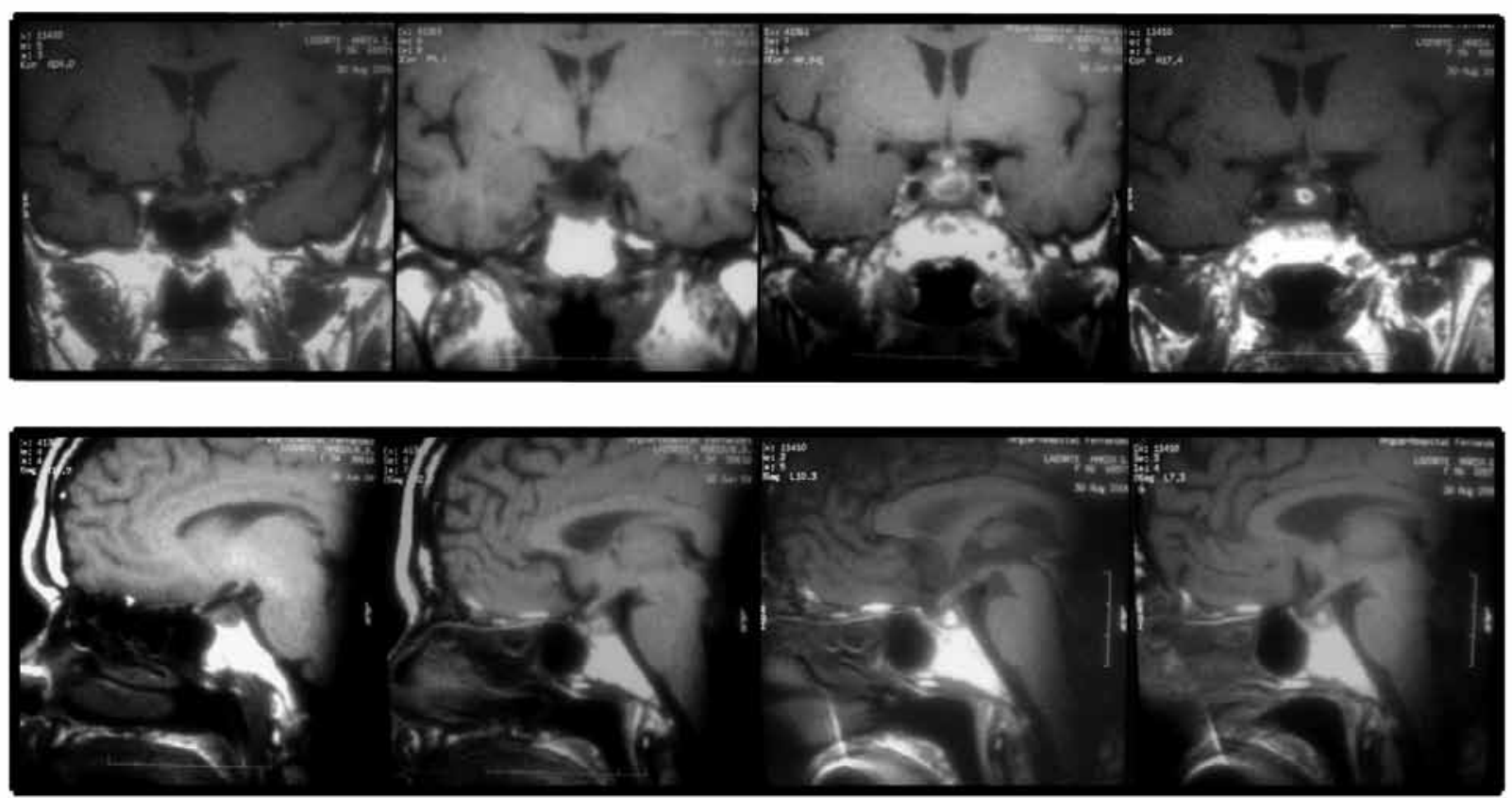

Figure 1. Basal MRI showing adenohypophysis ischemia, loss of hyperintensity of posterior pituitary, and thickening of the pituitary stalk. 


\section{DISCUSSION}

We present a patient with diagnosis of WG, based on pulmonary, renal, cutaneous and pituitary involvement, in the context of both ANCAc positive results and histology confirmation. In our patient, endocrine involvement was based on CDI, panhypopituitarism (central hypothyroidism and both deficit of the gonadal and growth hormone axes) and mild hyperprolactinemia. After instauration of systemic therapy with cyclophosphamide and steroids, the patient evolved satisfactorily, with partial recovery of her CDI. However, MRI pathological image persisted, and levothyroxine requirement was permanent, without normalization of gonadal or growth axes.

WG is a necrotizing granulomatous panvasculitis of the small vessels, which typically affects the upper respiratory tract, kidneys and lungs. Nevertheless, as it is multi-system condition, it can affect any organ. Thus, cutaneous, neurologic, and pituitary involvement, among other tissues, have been reported (3). Although WG affects males and females equally, it is interesting to highlight that the majority of patients with pituitary dysfunction are women, with reported a rate of $74 \%$ of the cases in women (8).

The presence of ANCAc is described in approximately $85 \%$ of the patients. Furthermore, there are specific diagnostic criteria of WG, which are mentioned in table 2. Final confirmation of the diagnosis is based on histological analysis $(3,9)$.

Table 2. Diagnostic criteria of $W G^{*}$

1. Nasal or oral inflammation or ulcer

2. Nodules, cavitations or non-migratory infiltrates in the chest $X$ ray

3. Alteration in urinary sediment: microhematuria or cell casts

4. Granulomatous inflammation or vasculitis in biopsy

* The presence of two or more items suggests the diagnosis.

As for pituitary involvement, although there is consensus that it may affect less than $1 \%$ of the patients with WG $(8)$, there are series that report pituitary dysfunction in approximately $8 \%$ of them (10). Furthermore, only as many as 24 cases have been reported in the literature from 1966 to $2011(6,7)$. The majority of the patients suffered from CDI combined with partial involvement of the anterior pituitary (11-16). However, exclusive anterior or posterior involvement have been reported as well $(6,16)$. Almost all cases of pituitary participation are combined with the involve- ment of other organs, especially the respiratory tract and kidneys, with only one case reported as isolated pituitary involvement (6).

With regard to the physiopathology of pituitary involvement in $\mathrm{WG}$, three main mechanisms have been proposed. The first one would be the direct involvement of vessels of the central nervous system, including the pituitary gland, with consequent secondary granulomatous hypophysitis. The second one would be the dissemination of granulomas from nearby anatomic areas, such as the sinus or orbits. Finally, the third one is the formation of new granulomas in the pituitary, due to direct involvement of the gland (13).

In relation to the clinical behavior of pituitary involvement in WG, as it was previously referred, it is mainly represented by any degree of CDI, combined with anterior hypopituitarism (17-19). Even though this could rarely be the presentation symptom (20), it generally appears more frequently with the progression of WG $(16,18)$. Moreover, while pituitary participation may evolve with partial recovery and an adequate clinical response to systemic therapy (21), in most of the cases it has not been reported to improve without specific endocrine replacement therapy (6). Isolated CDI or anterior pituitary involvement has also been reported, though in a lesser extent $(16,21)$. Finally, mild hyperprolactinemia has been described merely in two patients, primarily attributed to pituitary stalk involvement $(22,23)$.

Concerning MRI, the most frequent finding is pituitary enlargement, sometimes associated with thickening of the pituitary stalk, and loss of classic hyperintensity of the neurohypophysis. In addition, the adenohypophysis can also exhibit loss of intensity (6). In other cases, a sellar mass or cyst has been described (24). Both stalk thickening and loss of the hyperintensity of the neurohypophysis generally remain unaltered in spite of adequate general response to therapy (25).

Finally, WG therapy is based on cyclophosphamide generally associated with steroids. This scheme is justified by the fact that there would be nearly $\mathbf{5 0 \%}$ lesser chance of relapse in patients treated with combination of cyclophosphamide and steroids, than with steroids alone (6). However, as it was already mentioned, the course of pituitary involvement in WG is generally not parallel to the one of the general disease, and only approximately $11 \%$ of the reported cases had full pituitary function recovery with systemic therapy (6). 
Nevertheless, the number of patients reported with pituitary involvement in WG is too small to reach a positive conclusion. In patients who responded to systemic therapy, from the endocrine point of view, recovery was reported at around six months of therapy $(6,12)$.

In conclusion, although pituitary involvement in WG is not one of its classic disorders, it ought to be considered due to the frequency of approximately $8 \%$ in WG patients. Endocrine involvement is mainly represented by CDI combined with partial hypopituitarism. MRI generally exhibits pituitary enlargement, stalk thickening and loss of hyperintensity of the neurohypophysis. Only $11 \%$ of the patients respond to systemic therapy with cyclophosphamide and steroids. The majority of them require further permanent endocrine therapy.

Due to the nature of the disease, WG should be taken into account in cases of CDI with or without partial hypopituitarism, associated with renal, respiratory or sinus involvement, essentially if granulomatous vasculitis is suspected, MRI is compatible, and other more common sellar disorders have been ruled out (5).

Disclosure: no potential conflict of interest relevant to this article was reported.

\section{REFERENCES}

1. Carpinteri R, Patelli I, Casanueva FF, Giustina A. Pituitary tumours: inflammatory and granulomatous expansive lesions of the pituitary. Best Pract Res Clin Endocrinol Metab. 2009;23(5):639-50.

2. Bosch $X$, Guilabert A, Font J. Antineutrophil cytoplasmic antibodies. Lancet. 2006;368:404-18.

3. Gonzalez-Gay MA, Garcia-Porrua C, Pujol RM. Clinical approach to cutaneous vasculitis. Curr Opin Rheumatol. 2005;17(1):56-61.

4. Ahlström CG, Liedholm K, Truedsson E. Respirato-renal type of polyarteritis nodosa. Acta Med Scand. 1953;144:323-32.

5. Tao J, Dong Y. Pituitary involvement in Wegener's granulomatosis: a case report and review of the literature. Chin Med J. 2004;116:1785-8.

6. Yong TY, Li JY, Amato L, Mahadevan K, Phillips PJ, Coates PS, et al. Pituitary involvement in Wegener's granulomatosis. Pituitary. 2008;11(1):77-84.

7. McIntyre EA, Perros P. Fatal inflammatory hypophysitis. Pituitary. 2007;10(1):107-11.
8. Hoffman GS, Kerr GS, Leavitt RY, Hallahan CW, Lebovics RS, Travis WD, et al. Wegener granulomatosis: an analysis of 158 patients. Ann Intern Med. 1992;116:488-98.

9. Jennette JC, Falk RJ. Small vessel vasculitis. N Eng J Med. 1997;337:1512-23.

10. Vittaz L, Ramanoelina J, Mahr A. Pituitary involvement inWegener's Granulomatosis. Two cases. Press Med. 2004;33(22):1585-90.

11. Susuki H. Hypopituitarism due to granulomatous diseases (Wegener granulomatosis, Hand-Schüller-Christian disease, sarcoidosis. Ryoikibetsu Shokogun Shirizu. 1993;(1):123-6.

12. Moesgaard J, Kjaehr K, Thomsen BS, Nielsen E, Rasmussen K, Jørgensen JO. Cranial diabetes insipidus in Wegener's granulomatosis. Ugeskr Laeger. 2006;168(10):1040-1.

13. Spísek R, Kolouchová E, Jensovský J, Rusina R, Fendrych P, Plas $J$, et al. Combined CNS and pituitary involvement as a primary manifestation of Wegener granulomatosis. Clin Rheumatol. 2006(5):739-42.

14. Roberts GA, Eren E, Sinclair H, Pelling M, Burns A, Bradford R, et al. Two cases of Wegener's granulomatosis involving the pituitary. Clin Endocrinol (Oxf). 1995;42(3):323-8.

15. Nishio M, Uetani $K$, Suruda $T$, Kobayashi H, Funasako M, Ohata M. A case of Wegener's granulomatosis complicated by hypopituitarism. Nihon Kyobu Shikkan Gakkai Zasshi. 1992;(11):1981-5.

16. Lohr KM, Ryan LM, Toohill RJ, Anderson T. Anterior pituitary involvement in Wegener's granulomatosis. J Rheumatol. 1988;15(5):855-7.

17. Garovic VD, Clarke BL, Chilson TS, Specks U. Diabetes insipidus and anterior pituitary insufficiency as presenting features of Wegener's granulomatosis. Am J Kidney Dis. 2001;37(1):E5.

18. Xue J, Wang H, Wu H, Jin Q. Wegener's granulomatosis complicated by central diabetes insipidus and peripheral neutrophy with normal pituitary in a patient. Rheumatol Int. 2009;29(10):1213-7.

19. Berthier S, Gil H, Bonneville JF, et al. Wegener's disease and central diabetes insipidus. Ann Endocrinol (Paris). 2000;61(6):531-7.

20. Dutta $P$, Hayatbhat M, Bhansali A, Bambery P, Kakar N. Wegener's granulomatosis presenting as diabetes insipidus. Exp Clin Endocrinol Diabetes. 2006;114(9):533-6.

21. Goyal $Y$, Kucharczyk S, Keystone L. Granulomatous hypophysitis due to Wegener's Granulomatosis. AJNR. 2000;21:1466-69.

22. Seror R, Mahr A, Ramanoelina J, Pagnoux C, Cohen P, Guillevin L. Central nervous system involvement in wegener granulomatosis. Medicine (Baltimore). 2006;85:54-65.

23. Rosete A, Cabral AR, Kraus A, Alarcón-Segovia D. Diabetes insipidus secondary to Wegener's granulomatosis: report and review of the literature. J Rheumatol. 1991;18:761-5.

24. Fujisawa I. Magnetic resonance imaging of the hypothalamic-neurohypophyseal system. J Neuroendocrinol. 2004;16:297-302.

25. Pivonello R, De Bellis A, Faggiano A, Di Salle F, Petretta M, Di Somma $C$, et al. Central diabetes insipidus and autoimmunity: relationship between the occurrence of antibodies to arginine vasopressin-secreting cells and clinical, immunological, and radiological features in a large cohort of patients with central diabetes insipidus of known and unknown etiology. J Clin Endocrinol Metab. 2003;88:1629-36. 